\title{
CLUSTER AND R\&D AFFECTING THE COMPETITIVE ADVANTAGE OF THE MOULD AND DIE SECTOR IN THE THAI AUTOMOTIVE INDUSTRY
}

\author{
Wanno Fongsuwan ${ }^{1}$, Wawmayura Chamsuk $^{2}$, KanjanaTawinunt ${ }^{3}$, Sirorath Tiengtavaj ${ }^{4}$, \\ Suwaj Dansomboon ${ }^{4}$, Josu Takala ${ }^{5}$ \\ ${ }^{1}$ Rajabhat Rajanagarindra University, Thailand \\ ${ }^{2}$ Huachiew Chalearprakiet University, Faculty of Business Administration, Thailand \\ ${ }^{3}$ Rajamangala University of Technology Lanna, Thailand \\ ${ }^{4}$ Mahanakorn University of Technology, Thailand \\ ${ }^{5}$ University of Vaasa, Finland \\ Corresponding author: \\ Wanno Fongsuwan \\ Rajabhat Rajanagarindra University \\ Faculty of Management Science \\ 422 Maruphong Rd., Na Mueang, Muang Chachoengsao, Chachoengsao, 24000, Thailand \\ phone: $(+66) 38500000$ \\ e-mail: wannof2501@gmail.com
}

Received: 5 July 2017

Accepted: 16 November 2017
ABstract

This study concerned clusters as well as research and development affecting the competitive advantage of the Thai automotive industry's mould and die sector. The study of development, examination of the consistency of the structural equation model, and the direct influence of linkage and association of cluster, as well as research and development for competitive advantage of operational locations in the Thai automotive mould \& die sector was carried out as well. Data was collected from 320 mould and die industry operators in Thailand with the goal of obtaining key information to align the business direction in response to market opportunities. An additional goal was to elevate the competitiveness of the Thai automotive mould and die industry toward positive growth and continual sustainability.

KEYWORDS

competitive advantage, research and development, cluster, automotive parts, mould and die.

\section{Introduction}

The mould \& die industry is one of several basic sectors of other industries. The leading industrial countries enjoy continuous growth and development of the mould and die industry. The mould and die industry is responsible for creating the moulds and dies needed to form various materials to obtain the desired shape for the production of various goods and products [1]. The mould and die industry of most countries is the basic industry important for the production of all kinds of products such as cars, electrical appliances, communication devices, telephones and medical devices. Such products are continually produced in large numbers and with high precision. At present, there are more than 1,000 entrepre- neurs acting as the main supporting industries for the production of parts. It is necessary to accelerate the adaptation process to serve potential expansion. The quicker adaption can occur, the more the mould and die industry as well as related industries in the country and region will benefit. From a forecast of tendencies, car production is expected to grow continually until 2030. However, productivity in Japan appears to be decreasing. If compared to other industrial countries in Asia where Japan has a desire to invest in the automotive industry, it is apparent that Thailand is in the first rank, followed by Indonesia and India. For the automotive parts and spare parts industry, Thailand is in the first rank, followed by the Philippines and Vietnam. For the mould and die industry, Thailand is still in the first rank, followed 
by Indonesia and Vietnam. It can be seen that Japan tends to choose Thailand first when considering investment in the industries mentioned above [2], as shown in Fig. 1.

\section{Which country do Japanese makers} wish to go to ?

\begin{tabular}{|c|c|c|c|}
\hline \multicolumn{4}{|l|}{ Car makers } \\
\hline \multicolumn{4}{|c|}{ Car Parts makers } \\
\hline 1. Thailand & 2. Philippine & 3. Vietnam 4. India & 5. Indonesia \\
\hline \multicolumn{4}{|c|}{ Die \& Mould makers } \\
\hline $\begin{array}{c}\text { 1. Thailand } \\
\downarrow \\
\text {-well appointed } \\
\text { infrastructure } \\
\text {-needs from } \\
\text { Japanese } \\
\text { car makers } \\
\text {-pro-Japanese }\end{array}$ & $\begin{array}{c}\text { 2. Indonesia } \\
\downarrow \\
\text {-needs from } \\
\text { Japanese } \\
\text { car makers } \\
\text {-pro-Japanese }\end{array}$ & - 3. Vietnam 4 & 1. Philippine \\
\hline
\end{tabular}

Fig. 1. Countries chosen by Japan, in order of preference, for investment in the automotive industry and related industries [2]

Thailand exports moulds and dies to various countries. When comparing the value that Thailand has to import mould and die products, it can be seen that Thailand has very high import value each year for the mould and die industry. In 2014, the import value of mould and die reached its highest point to date, accounting for 4.2 times the export value. To put it in perspective, the import value was 40,450.3 million baht, while the export value was only $9,564.7$ million baht. The main industries with high import value for moulds and dies are the automotive industry, electrical and electronics industries, plastic industry, and rubber industry. However, Thailand imported moulds and dies in a declining proportion in 2015 when compared to 2014. The import value of $28,426.8$ million baht was a decrease of 29.7 percent from the previous year. Meanwhile, the export value of moulds and dies gradually increases by 14.1 percent, accounting for about 10,913.8 million baht [3].

In 2015, Thailand exported moulds and dies to several countries. The major export countries for Thailand include Japan, Indonesia, India, Vietnam, Argentina, South America, USA, China, Malaysia, and Brazil, among others. The most moulds and dies were exported to Japan, accounting for 2,123.87 million baht (2,085.08 million pieces), followed by Indonesia and India with a value of 1,420.90 million baht (2,545.49 million pieces) and 970.84 million baht (1,552.13 million pieces) [3].

The operators in the mould and die industry will cluster to link between groups of operators in the mould and die industry and other related down- stream operators such as the automotive and automotive parts sectors, electrical and electronics industries, and household appliance industry [1]. One of the important policies for economic development is to move forward to become a country with global competitive potential. This involves the promotion of cluster development. A "cluster" is a key tool and mechanism for increasing the competitiveness and industrial economic development of countries, including Thailand [4]. This corresponds to studies by Sölvell Ö., Lindqvist G., Ketels C. [5], who stated that a cluster is a mutually-dependent grouping focused on the true contribution of all sectors. One approach that creates a strategic advantage for the industry in business can be used as a tool for creating competitive advantage. In addition, research and development is another significant tool for operators in creating competitive advantage [6]. This is consistent with the study of Sandeep Salunke et al. [7], who revealed that a company focusing on expansion and modification of processes in building and maintaining capabilities critically will succeed in research and development, thus achieving a sustainable competitive advantage. Many businesses seek ways to achieve sustainable success and create competitive advantage [8]. Research and development is concerned with the ability of organizations to engage in creating differentiation and boosting competitiveness. New process research and development, new product research and development, and new ideas in the organization are some examples.

From the significance of the issues mentioned above, this researcher is interested in studying the clustering, research and development of factors affecting competitive advantage in the Thai automotive industry, particularly for the mould and die sector. This study focuses on the development and checks for consistency of the structural equation model. It also studies the direct effects of linkage of clusters, research and development, as well as the competitive advantage of operational locations for the mould and die industry in automotive parts in Thailand. The goal is to obtain key information to align the direction of business corresponding to market opportunities. This can improve the competitiveness of the automotive mould and die parts industry for continuous and sustainable growth.

Objectives of the study

- To study the direct and indirect effects of variables for competitive advantage in the Thai automotive industry for the mould and die sector.

- To develop a structural equation model for variables that effect competitive advantage in the Thai automotive industry for the mould and die sector. 


\section{Literature review}

\section{Cluster}

In the globalization era, various countries must be linked to rely on each other. Only countries that are competitive and capable are ready to compete for survival and sustainable growth. In order to raise the economic base of the country to the next level for businesses to survive, therefore, it is necessary to increase competitiveness at the international level, especially for the countries in the ASEAN Economic Community (AEC). This is considered an important step to help Thailand achieve a sustainable economy. To reach that point, the involvement of all parties is required, whether from the public, private or academic sectors. This also includes other related agencies that can help to increase the competitive advantage of one another and promote the country's economy toward sustainable growth. One of the key policies in economic development to move towards becoming a country with global competitive potential is to promote cluster development. A "cluster" is a powerful tool and mechanism for enhancing competitiveness and the development of an industrial economy in a country. When considering success for industry in developed or developing countries, it is apparent that successful industries do not come from a single company or entity alone. Rather, it comes from multiple ventures competing in clusters, resulting in sustainable economic growth [4]. Porter M. [32] stated that a cluster is a group of businesses and related institutions involved in the same business with cooperative linking and complementing. The links involve business operators from upstream to downstream, while a horizontal link connects various supporting industries including business services, trade associations, educational institutes, and training institutes, as well as research and development institutes and other relevant government agencies in order to achieve mutual goals. One of the key factors driving the success of this network development mechanism is the allocation of financial benefits to the business [33]. It can be said that a cluster of investors is capable of creating a relationship among the group members that can lead to new markets and create marketing channels, which leads to increased productivity and strengthens the existing groups or facilitating an upcoming cluster $[34,35]$ with numerous competitive pressures. The businesses in the group are often stimulated to increase efficiency, promote research and development and improve business performance [36].

The development of cluster potential requires the creation of knowledge, understanding, awareness and networking among members in the network on the basis of trust in order to encourage members to see the importance and need for cooperation to enhance their competitiveness [37]. According to the study of Yen-Tsung Huang [38], knowledge gained from a joint venture through the cooperation of both parties to bring the obtained knowledge to merge with the original knowledge can result in the ability of research and development in the organizations to increase the chances of success. According to the study by Sohel Ahmad and Roger G. Schroeder [39], adaptation in the process to use technological cooperation will be a driving force for mutual benefits. This is consistent with Langlois [40], who found that a cluster is an investment in the collaborative relationships between businesses for the exchange or sharing of information and resources. The restrictions include only direct and official cooperation. It also overlooks the critical issue of comparable capabilities with non-affiliated entities. This is also consistent with Sölvell Ö., Lindqvist G., Ketels C. [5], who stated that a cluster is a mutually-dependent grouping that focuses on the real participation of all sectors. One approach that creates a strategic advantage for the industry in business may be used as a tool in creating competitive advantage. This is also found to be consistent with the study of Xiujie Wang et al. [41] which was a collaborative study of the automotive industry based on collaborative efforts to research and develop mutual benefits. Tom Broekel et al. [42] found that clustered networking lead to research and development as well as collaboration. Ma Ding [43] found that collaboration in the supply chain could work together in creating research and development.

\section{Competitive advantage}

Michael E. Porter [9] stated that the creation of important strategies for competitive advantage consists of Cost Strategy, which involves trying to conduct activities to cut costs and thus create competitive advantage. Regarding the Difference Strategy, customers nowadays have various needs that cause sellers to have to differentiate from other sellers. Research, technology development, and innovation may be conducted to make a difference more than focusing on a strategy to provide services to the group of customers with the same preferences in response to the needs of niche customers. This includes those who enjoy new technologies for use in conjunction with their lifestyles and daily routines. Competitive advantage has also been set in the operation of companies to become leaders in quality, delivery, flexibility and low cost [10]. Wang, Chi-Tai, and ChuiSheng [11] stated that creating competitive advan- 
tage must involve starting development in terms of speed, cost, flexibility and quality. The creation of value, sustainability and branding will help create competitive advantage for organizations $[12,13]$. The fact that companies use the processes and product research and developments provides competitive advantage in terms of cost and market differentiation [14]. In response to global competition, manufacturers must cope with high product diversity, short product life cycle, and increasing product development costs [15]. The study by Watchara Yeesoontes and Witayakorn Chiengkul [16] focused on the competitiveness of the mould and die industry in Thailand. They found that competitiveness for finding the comparative competitive advantage index in the mould and die industry showed that the Thai mould and die industry had less competitive advantage in comparison to Japan, Korea, Taiwan and Singapore. However, the trend is improving for Thailand. The growth rate has increased in line with the country's GDP, changing at a rate that is in line with major continuing changes in the automotive industry. Lui and Jiang Wai [17] found that competitive advantage in the business model was incorporated in value research and development, which affects the cost focus and results in the value of differentiation. It also leads to competitive advantage. Most businesses seek ways to achieve sustainable success and create competitive advantage [8].

\section{Research and development capability}

The operational approaches necessary for operators nowadays inevitably require development, improvement, and change due to serious competition in the market. This research presents one idea for creating competitive advantage for operators as well as being able to help develop organizations for future growth [18]. Organizations having the ability to research and develop processes for the creation of innovation are considered one of the changing processes causing the operations and organizations to have capabilities [19]. The research and development capability is applied broadly depending on each agency. Further, such capability tends to be used differently by each business, such as focusing on research and development for increased quality and efficiency in existing products or services for market competitiveness [20]. Un, C. Annique et al. [21] studied cooperation in research and development, both inside and outside organizations. The result was improvement of innovation for processes, management, research and development beneficial for developing the innovations and support from the government in the investment of researches and development.
The operational performance of organizations can be observed from sustainable and increasing market shares. However, Colomboa Massimo G. and Rabbiosi Larissa [22] created a technological linkage to the research and development with influence on the creation of innovation to link the research and development of processes with the improvement of research and development influencing efficiency in the operations. Moreover, Wang, Chun-Hsien et al. [23] found that the organizations with efficient research and development throughout the value chain can increase the efficiency, profitability, and creation of marketing strategies in order to maintain competitive advantage. Organizations with research and development need to be very focused on time and investment, including the determination of the organizations to have the capacity to dedicate research and development as well as the creativity obtained from new research and development capacity $[24,25]$. The research and development capacity can be classified as follows: 1) Product Research and Development is the development and improvement of products and innovation in the organizations for increasing the research and development capacity occurring in the organizations [25, 26, 27, 28], 2) Process Research and Development is the development and improvement of processes and innovation to increase the research and development capacity to occur in the organizations [26, 28, 29], 3) Research and Development Management is the creation and stipulation of an organization's goals to allow everyone to work altogether in order to increase the research and development capacity and allow it to occur in the organizations efficiently [26, 30, 31].

After review of relevant literature, the research model can be developed, as shown in Fig. 2. Further, the following hypotheses can be presented:

Hypothesis 1: Cluster has positive and direct effects on research and development

Hypothesis 2: Cluster has positive and direct effects on competitive advantage

Hypothesis 3: Research and development has positive and direct effects on competitive advantage

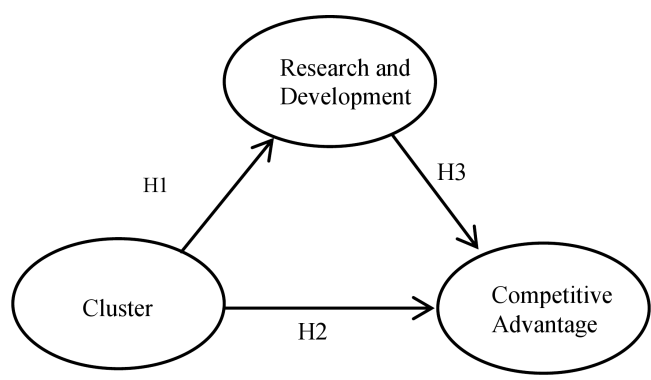

Fig. 2. The conceptual framework. 


\section{Methodology}

\section{Data collection and data analysis}

In this research, samples comprised 320 operators in the mould and die industry of Thailand [44]. The questionnaires were constructed as a tool for measurement based on the conceptual framework and practical definition. The creation of the measuring instrument, or questionnaire, will use a 7-point Likert Scale [45], as shown in Table 1. A total of 5 experts examined the consistency of the questionnaires and found the IOC values. Questions with IOC values over 0.5 were used. After that, the updated questionnaire was used to collect sample data from 30 samples for measurement using the internal consistency method with Cronbach's alpha coefficients $(\alpha-$ coefficient), which were utilized to calculate the mean of the obtained correlation coefficient. If the value was less than 0.50 , the researcher removed the question data. The analysis on the accuracy and reliability of the measurement as well as the inspection of measurements used the internal consistency method with Cronbach's alpha coefficients ( $\alpha$-coefficient) to calculate the mean of the obtained correlation coefficient. It was found that the alpha coefficient ranged from $0.835-0.926$, which is considered to be highly reliable.

Table 1

Standard criteria of correspondence.

\begin{tabular}{l|c|c}
\hline Related statistics & Symbols & Criteria \\
\hline Chi-square & $\chi^{2}$ & Ns. $(\mathrm{p}>.05)$ \\
\hline Relative Chi-square & $\chi^{2} / \mathrm{df}$ & $\chi^{2} / \mathrm{df}<2.00$ \\
\hline Goodness of Fit Index & GFI & $>.90$ \\
\hline Comparative Fit Index & CFI & $>.95$ \\
\hline Normal Fit Index & NFI & $>.90$ \\
\hline Adjusted Goodness of Fit Index & AGFI & $>.90$ \\
\hline $\begin{array}{l}\text { Root Mean Square Error } \\
\text { of Approximation }\end{array}$ & RMSEA & $<.05$ \\
\hline$[44,46]$ & & \\
\hline
\end{tabular}

Regarding the data analysis in this research, the researcher chose to use a program to help analyze the relationship between variables and apply the structural equation model (SEM) or the causal relationship analysis between variables. By using correlational research with high statistical analysis and the variation form between variables, the researcher considered the size of the sample group and the population used in this research, which comprised a ratio of 20 samples per 1 variable. Schumacker \& Lomax [46] stated that analysis on a structural equation model (SEM) required the definition of larger sample sizes through analysis with other approaches in order to gain the correct estimation as well as to be able to represent the population well. Hair et al. [44] stated that the size of the sample group was large enough to be used in the data analysis when applying the structural equation model and normal curve.

\section{Research analysis and results}

\section{Measurement model analysis}

The Measurement Model by Confirmatory Factor Analysis (CFA) used a program with parameter estimation of Maximum Likelihood (ML), which can be conducted by analyzing the Reflective Measurement variables. The statistics used in examining the correspondence and the harmonization between the models and the empirical data (Goodness of Fit Measures) will use acceptable standard criteria, as shown in Table 1.

The operation on the convergent validity and the discriminant validity with the measurement of convergent validity will have the criteria in consideration that the indicator loading has the statistical significance (t-Value (C.R.) > 1.96). This shows that the measurement has convergent validity (Lauro and Vinzi, 2004; Henseler, Fassott, 2010). For the discriminant validity of the internal latent variables in the reflective model, $\mathrm{R} 2$ value should not be less than $0.20[47,48]$. According to Table 2, it was found that

Table 2

Results of the measurement model (confirmatory factor analysis).

\begin{tabular}{l|l|c|c|c|c}
\hline Research Constructs & Research Items & Standardized Loading & t-test & $\mathrm{p}$ & $\mathrm{R}^{2}$ \\
\hline Cluster & Partner & .648 & 11.497 & .000 & .42 \\
& Activity & .714 & 12.497 & .000 & .51 \\
& Resource & .788 & 14.425 & .000 & .62 \\
& Value & .803 & & .64 \\
\hline Research and development & Product R\&D & .716 & 13.609 & .000 & .51 \\
& Process R\&D & .829 & & .69 \\
& Management R\&D & .828 & 16.499 & .000 & .69 \\
\hline Competitive Advantage & Quality & .651 & .601 & .000 & .42 \\
& Cost & .810 & & .66 \\
& Delivery & .144 & 2.311 & .021 & .20 \\
\hline
\end{tabular}

Notes. All factor loadings are standardized and significant to a level of .05 
the component weight of the cluster variable ranged from $0.648-0.803$. The component weight for the research and development variable ranged from 0.716 0.828. The component weight for the competitive advantage variable ranged from $0.144-0.810$. When considering each component with statistical significance (t-Value (C.R.) > 1.96), R2 ranged from 0.200.69 , which is not less than 0.20 and shows that the measurement is reliable.

\section{Structural equation model analysis}

The structural equation model analysis is a technique for analyzing the multiple variables combining factor analysis and multiple regression. Using such a technique is beneficial for a researcher when examining relationships between variables in the same time [44]. The statistical program used in examining the SEM is the used program. According to the results of examination for correspondence and harmonization between the conceptual framework and the empirical data, it was found that the structural equation model contained harmonization with the empirical data (Model Fit) (Fig. 3), as shown by the following values: Chi-square $\left(\chi^{2}\right)=44.247, \mathrm{df}=34, \mathrm{p}=$ $0.112, \chi^{2} / \mathrm{df}=1.301, \mathrm{GFI}=0.973, \mathrm{NFI}=0.974$, $\mathrm{CFI}=0.994, \mathrm{TLI}=0.990$ and $\mathrm{RMSEA}=0.032$.

\section{Hypothesis test result}

Hypothesis 1: A cluster has a positive and direct effect on research and development. The hypothesis test results revealed a standard correlation coefficient $($ coef. $)=0.908$ with the reality acceptable from the hypothesis and statistical significance at the .05 level.

Hypothesis 2: A cluster has a positive and direct effect on competitive advantage. The hypothesis test results revealed a standard correlation coefficient (coef. $)=0.478$ with the reality acceptable from the hypothesis and the statistical significance at the .05 level.

Hypothesis 3: Research and development has a positive and direct effects on competitive advantage. The hypothesis test results reveal to have the standard correlation coefficient (coef.) $=0.442$ with the reality acceptable from the hypothesis and the statistical significance at the .05 level.

The results of analysis for the structural equation model are as follows:

Research and development $=0.91$ Cluster,

$$
R^{2}=0.82,
$$

\section{Competitive Advantage $=0.44$ Cluster}

+0.48 Research and development,

$$
R^{2}=0.81 \text {. }
$$

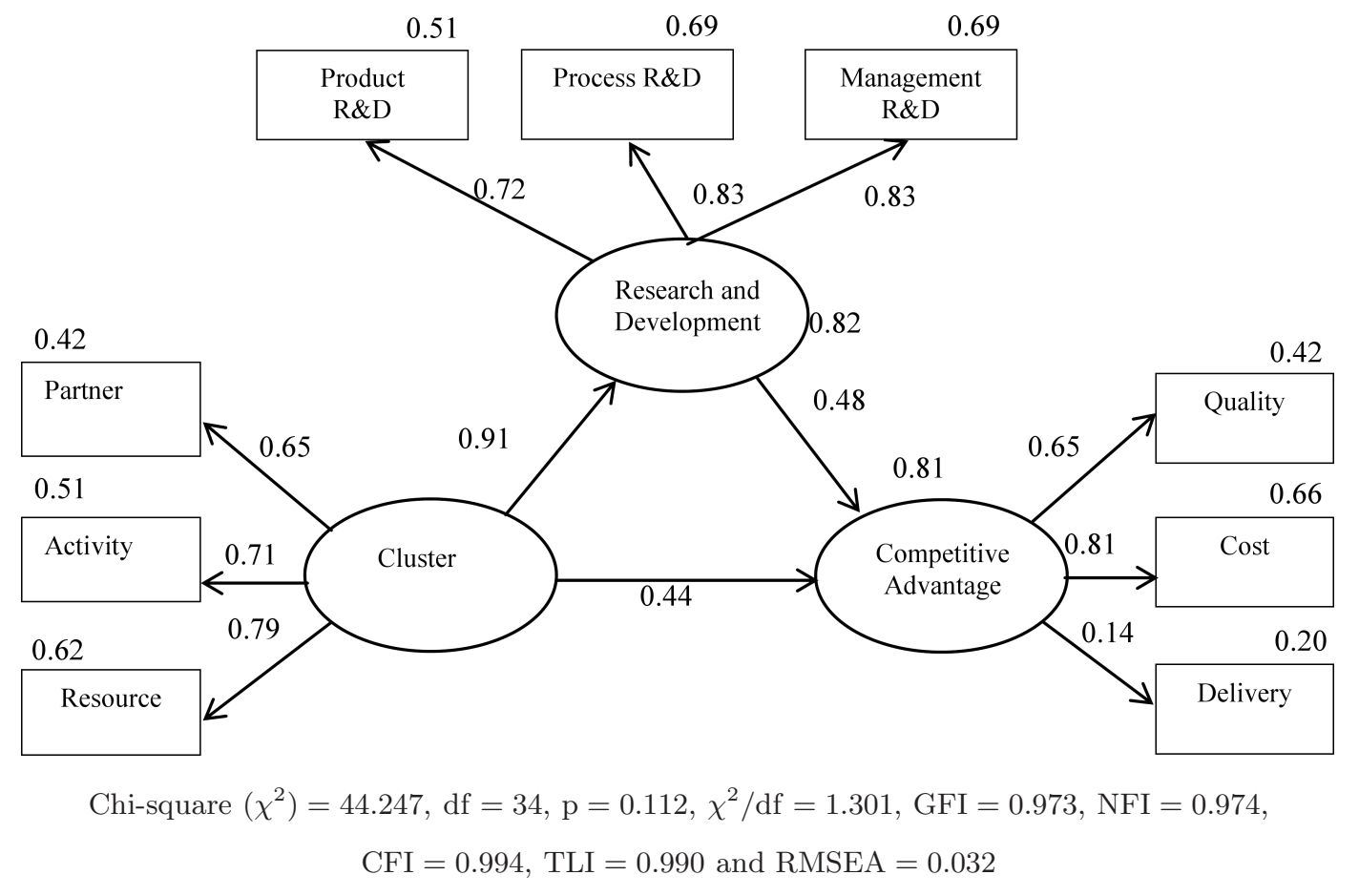

Fig. 3. Final model. 
Table 3

Hypothesis testing result.

\begin{tabular}{l|c|c|c|c|c|c}
\hline Hypothesis & Coefficient & t-test & Total effects & Direct effects & Indirect effects & Results \\
\hline H1 $:$ RD $<-\mathrm{CT}$ & .908 & 9.758 & .908 & .908 & - & Supported \\
\hline H2 $:$ CA $<-\mathrm{CT}$ & .478 & 2.424 & .880 & .478 & .401 & Supported \\
\hline H3: CA $<-\mathrm{RD}$ & .442 & 2.302 & .442 & .442 & - & Supported \\
\hline
\end{tabular}

Note: Research and development (RD), Cluster (CT), Competitive Advantage (CA)

\section{Discussion and implementation}

From the research results on clusters and research and development that affect competitive advantages in the automotive mould and die industry of Thailand, certain issues can be discussed as follows.

The cluster factor for automotive mould and die parts producers has a positive effect on competitive advantage. This corresponds with the findings of Yen-Tsung Huang [38], who found that knowledge gained from joint ventures through the cooperation of both parties combines the obtained knowledge for merger with the original knowledge. This results in the ability of organizational research and development to increase the chances of success [49]. Investment in research and development not only involves enforcement to create technological research and development, it can also generate learning from both inside and outside the organization. Any organization with an agency or department for research and development will be able to effectively integrate knowledge from outside the organization. Therefore, it can be concluded that research and development competency has a positive effect on competitive advantage $[25,50]$.

Clustering directly influences the capacity for research and development. This corresponds with Xiujie Wang et al. [41], who studied the mechanism for working together in research and development for an automotive group. They utilized the cooperation of industrial ecology theory, biological evolution and innovation theory. The group of cluster industry indicates that the automotive group industry system contains innovation, resulting in mutual benefits and development. The mechanism is created for generating innovation mutually in the automotive industrial group by using the cooperation from the group in solving and analyzing. Tom Broekel et al. [42] studied the cluster, innovation, and cooperation in the research and development network. The allocation of contributions that support research and development focuses on the success of the organization. The networks working altogether in research and development for contribution show that clustering is likely to be contributory for mutual research and devel- opment to create the innovation. Besides, Ma Ding [43] studied the impact of working together in a supply chain and the effect on innovation. He found that cooperation in the supply chain and the capability to work together in creating innovation had a positive effect on environmentally-friendly innovations. Moreover, research and development inside organizations also promotes relationship building between environmental-friendly innovations to create more productive and efficient innovation.

Research and development capabilities have a direct influence on competitive advantage. This idea corresponds with Joongsan Oh, Seung-Kyu Rhee [25], who studied the research and development capability in engineering, design, and modularization. There is a direct influence on competitive advantage. Endang Chumaidiyah [51] found that the reduction of customers and income was caused by the fact that the organizations had to encounter changes in new technologies. Therefore, organizations have to maintain the outstanding characteristics of resources such as technology, particular skills, and research and development capabilities in order to increase productivity and profits. Moreover, the research results revealed that technology, particular skills, and research and development capabilities significantly influence competitive advantage. This could serve as a guideline for developing and building the strength of organizations as well as creating competitive advantage. However, Mazharul Islam and Azharul Karim [52] stated that the development of quality products would satisfy customers. There must be production management and a relationship between the supply chain networks to transfer or exchange data between each other. Sohel Ahmad and Roger G. Schroeder [39] stated that technological cooperation must be used as a driving force in the adjustment of processes for mutual benefit. It can also be concluded that research and development has a positive effect on competitive advantage [26].

\section{Conclusion}

In Thailand, the mould and die industry has developed and focused on competitiveness with other 
countries in the same region, both for the quality of moulds and dies as well as the development of skills by Thai labor. The focus has also extended to creating competitive advantage by emphasizing on cost, quality and timely delivery. At present, it is apparent that the Thai mould and die industry continues to pay insufficient attention to the development of technological research and development, especially among small companies, resulting in incremental research and development in the industry. From study of the research and development capacity as well as clusters that affect the competitive advantage of the automotive mould and die industry in Thailand, the findings reveal that the clusters in the mould and die industry remain an important factor for research and development both inside and outside the organizations in order to be competitive with foreign countries. Thus, elevating the capabilities of the industry to support the production of high quality components and serve the automotive industry is essential. In order to produce quality parts, the development of mould and die techniques and related tools is very important. However, $90 \%$ of the production in the mould and die industry, as well as related industries in Thailand, is done by small and medium-sized companies. Moreover, the use of computer systems for the design of moulds and dies has been insufficient due to the lack of knowledge and expertise. The government has a desire to restructure the economy to be balanced and sustainable by focusing on the restructuring of production, linking multinational business in technological transfer, domestic research and technological development, and the development of skills by personnel in the mould and die industry, including the development of operators for adaption to future competition.

\section{References}

[1] Ministry of Industry, Master Plan for Thai Industry Development B.E.2555-25\%4, 2016, Accessible from:tsba.or.th/download/National\%20industrial\% 20developmen\%20master\%20plan.pdf].

[2] Yoshinori Maekawa, Desirable Collaboration between Thailand and Japan for Die and Mould Technology, Thailand-Japan Die and Mould Technology Symposium, November 22, 2012.

[3] Thai Customs Department, Statistics of importexport, http://internet1.customs.go.th/ext/Statistic/StatisticIndex2550.jsp [accessed on September 10, 2016].

[4] The Secretariat of the House of Representatives, Cluster: Business cluster for competition,2015, http://www.parliament.go.th/library [accessed on September 10, 2016].

[5] Sölvell Ö., Lindqvist G., Ketels C., The Cluster Initiative Greenbook Stockholm: Ivory Tower, 2003, http://www.cluster-research.org [accessed on March 1, 2016].

[6] Zhao F., Managing Innovation and Quality of Collaborative $R \& D$, International \& 8 th Nation Conference, Melbourne, 2001.

[7] Salunke S., Weerawardena J., McColl-Kennedy J.R., Towards a model of dynamic capabilities in innovation-based competitive strategy: insights from project-oriented service firms, Industrial Marketing Management, 40, 1251-1263, 2011.

[8] Weng M.H., Ha J.L., Wang Y.C., Tsai C.L., A study of the relationship among service innovation customer value and customer satisfaction: an industry in Taiwan, International Journal of Organizational Innovation, 4, 3, 98-112, 2012.

[9] Porter M.E., Competitive Advantage Creating and Sustaining Superior Performance, The Free Press, New York, 1985.

[10] Mehmet Murat Kristal, Xiaowen Huang, Aleda V. Roth, The effect of an ambidextrous supply chain strategy on combinative competitive capabilities and business performance, Journal of Operations Management, 28, 415-429, 2010.

[11] Wang Chi-Tai, Chiu Chui-Sheng, Competitive strategies for Taiwan's semiconductor industry in a new world economy, Technology in Society, 36, 60-73, 2014.

[12] Soloducho-Pelc L., Competitive advantage: the courage in formulating objectives and expansiveness of a strategy, Procedia- Social and Behavioral Sciences, 150, 271-280, 2014.

[13] Verma Rajeev, Jayasimha K.R., Service delivery innovation architecture: an empirical study of antecedents and outcomes, IIMB Management Review, 26, 105-121, 2014.

[14] Kam-Sing Wong S., The influence of green product competitiveness on the success of green product innovation Empirical evidence from the Chinese electrical and electronics industry, European Journal of Innovation Management, 15, 4, 468-490, 2011.

[15] Kotler P., A Framework for Marketing Management, Second Ed. Pearson Education International, New Jersey, 2003.

[16] Watchara Yeesoontes, Witayakorn Chiengkul, The Competitiveness of Thailand's Mould and Die Industry, 2013, http://opac.lib.buu.ac.th, [accessed on August 11, 2016]. 
[17] Liu Y., Wei J., Business modeling for entrepreneurial firms: four case in China, Chin. Manag. Stud., 7, 3, 344-359, 2013.

[18] Kyung-Nam Kang, Hayoung Park, Influence of government R\&D support and inter-firm collaborations on innovation in Korean biotechnology SMEs, Technovation, 32, 68-78, 2012.

[19] Magrab E.B., Gupta S.K., McCluskey F.P., Sandaborn P.A., Integrated Produc and Process Design and Development, New York, CRD Press Taylor \& francis Group, 2009.

[20] Chamsuk W., Fongsuwan W., Takala J., The effect of research and development capability on competitive advantage: a SEM approach an automotive parts industry in Thailand, Management and Production Engineering Review, 8, 1, 101-112, 2017.

[21] Un C. Annique, Asakawa, Kazuhiro, Types of R\&D Collaborations and Process Innovation: The Benefit of Collaborating Upstream in the Knowledge Chain, Journal of Product Innovation and Management, $32,1,138-153,2015$.

[22] Colomboa M.G., Rabbiosi L., Technological similarity, post-acquisition $R E B D$ reorganization, and innovation performance in horizontal acquisitions, Research Policy, 43, 1039-1054, 2014.

[23] Wang Chun-Hsien, Lu Yung-Hsiang, Huang ChinWei, Lee Jun-Yen, REDD, productivity, and market value: An empirical study from high-technology firms, Omega, 41, 143-155, 2013.

[24] Lau Antonio K.W., Yam R.C.M., Tang E., The complementarity of internal integration and product modularity : An empirical study of their interaction effect on competitive capabilities, J. Eng. Technol. Manag., 26, 305-326, 2009.

[25] Joongsan Oh, Seung-Kyu Rhee, Influences of supplier capabilities and collaboration in new car development on competitive advantage of carmakers, Management Decision, 48, 5, 756-774, 2010.

[26] Wawmayura Chamsuk, Phimonsathien T., Wanno Fongsuwan, A Structural Equation Model of factors that affect the ASEAN Competitive Advantage of the Thai Automotive Parts Industry, Research Journal of Business Management, 9, 1, 218-232, 2015.

[27] Pelin Bicen et al., Validating new product creativity in the eastern context of Malaysia, Journal of Business Research, JBR-07578, 7, 2014.

[28] Ming Lang Tseng, Sheng Hsiang Lin, Truong Nguyen Tuong Vy, Mediate effect of technology innovation capabilities investment capability and firm performance in Vietnam, Procedia - Social and Behavioral Sciences, 40, 817-829, 2012.
[29] Angappa Gunasekaran, Alain Spalanzani, Sustainability of manufacturing and services: investigations for research and applications, Int. J. Production Economics, 140, 35-47, 2012.

[30] Yeonhee Lee, Sooyoung Kim, Hyejin Lee, The impact of service $R E B D$ on the performance of $\mathrm{Ko}$ rean information communication technology small and medium enterprises, Journal of Engineering and Technology Management, 28, 77-92, 2011.

[31] Prajogo D.I., Sohal A.S., The integration of TQM and technology/RED management in determining quality and innovation performance, Omega, 34, 296-312, 2006

[32] Porter M.E., Clusters and the New Economics of Competition, Harvard Business Review, 76, 6, 7790, 1998.

[33] Martin R., Sunley P., Deconstructing Clusters, Chaotic Concept or Policy Panacea?, 2003.

[34] Cane T., Tyler B.B., Alliance portfolio RED intensity and new product introduction, Am. J. Bus., 28, 1, 38-63, 2013.

[35] Santos-Vijande M.L., Lopez-Sanchez J.A., Trespalacios, J.A., How organizational learning affects a firm's flexibility, competitive strategy, and performance, J. Bus. Res., 65, 1079-1089, 2012.

[36] Porter M.E., Competitive advantage of nations: creating and sustaining superior performance, Simon and Schuster, 2011.

[37] Rodriguez-Clare A., Coordination Failures, Clusters and Microeconomic Interventions. Inter-American development, Bank Working Paper, 2005.

[38] Yen-Tsung Huang, Learning from cooperative interorganizational relationships: the case of international joint venture, Journal of Business \& Industrial Marketing, 25, 6, 454-467, 2010.

[39] Sohel Ahmad, Schroeder R.G., Knowledge management through technology strategy: implications for competitiveness, J. Manuf. Tech. Manag., 22, 1, 624, 2011.

[40] Langlois R.H., Competition through Institutional Form: the Case of Cluster Tool Standards, University of Connecticut Department of Economics, Working Paper No.2004-10, 2004, Available at SSRN: http://ssrn.com/abstract $=594542$.

[41] Xiujie Wang, Jian Liu, Research on the Collaborative Innovation Mechanism of the Automotive Industry Cluster Based on Original Collaboration, 3rd International Conference on Management, Education, Information and Control (MEICI 2015), pp. 1627-1631, 2015.

[42] Broekel T., Fornahl D., Morrison A., Another cluster premium: innovation subsidies and RED collab- 
oration networks, Papers in Evolutionary Economic Geography, pp. 1-30, 2015.

[43] Ma Ding, Supply Chain Collaboration toward Ecoinnovation: an SEM Analysis of the Inner Mechanism, 978-1-4799-6058-3/14/\$31.00, IEEE, pp. 129134, 2014.

[44] Hair J.F. Jr., Black W.C., Babin B.J., Anderson R.E., Multivariate data analysis (7th ed.), New Jersey, USA: Prentice Hall, 2010.

[45] Likert R., A Technique for the Measurement of Attitudes, [in:] Attitude Assessment, Summers G.F. [Ed.], Rand-McNally and Company, Chicago, IL, USA, pp. 149-158, 1970.

[46] Schumacker R.E., Lomax R.G., A beginner's guide to structural equation modeling, New York: Routledge, 2010.

[47] Lauro C., Vinzi V.E., Amato S., PLS typological regression: algorithmic, classification and validation issues, [in:] New developments in classification and data analysis, Vichi M., Monari P., Mignani S., Montanari A. [Eds.], Springer-Verlag, Berlin, Germany, ISBN-13: 9783540238096, pp. 133-140, 2005.
[48] Henseler J., Fassott G., Testing moderating effects in PLS path models: An illustration of available procedures, 2010, Handbook of Partial Least Squares Springer Handbooks of Computational Statistics, pp.713-735.

[49] Bobillo A.M., Lopez-Iturriaga F., Tejerina-Gaite F., Firm performance and international diversification: the internal and external competitive advantages, International Business Review, 19, 607-618, 2010.

[50] Binder M., Gust P., Clegg B., The importance of collaborative frontloading in automotive supply networks, Journal of Manufacturing Technology Management, 19, 3, 315-331, 2008.

[51] Endang Chumaidiyah, The Technology, Technical Skill, and RED Capability in Increasing Profitability on Indonesia Telecommunication Services Companies, Procedia Economics and Finance, 4, 110-119, 2012.

[52] Mazharul Islam, Azharul Karim, Manufacturing practices and performance comparison among small-medium and large industries, Int. J. Qual. Reliab. Manag., 28, 1, 43-61, 2009. 